\title{
Heat Transfer Prediction of a Zeolite Bed Through Addition of Metal Additives
}

\author{
*Andi Taufan, Umi Hanifah \\ Research Center for Appropriate Technology, Indonesian Institute of Sciences, Jakarta 12710, Indonesia. \\ * Corresponding email: andi022@lipi.go.id
}

\begin{abstract}
This paper investigates the effect of metal additive thorough an adsorption bed. The bed is composed of zeolite granules on the inside diameter of a cylinder. A volume-based two-phase effective thermal conductivity formula was used to predict the thermal conductivity of two components mixture. Energy balance is also discussed to ensure the time needed to spread the heat to all bed body. The results show that aluminium enhances thermal performance better than other metal additives. The thermal conductivity of $15 \%$ wt of aluminium improves $286 \%$ compare to the zeolite thermal conductivity, followed by copper, brass, and steel of $217 \%, 188 \%$, and $115 \%$, respectively.
\end{abstract}

Key words : Alumunium, Metal additive, Thermal conductivity, Zeolite granules

\section{INTRODUCTION}

Energy and renewable energy studies about of adsorptive system utilization are increasing in recent years. Many researchers utilized adsorbent to make greener technology such as adsorption heat pump, adsorption cooling system, or desiccant system as humidifier up to agricultural dryer [1]-[4]. However, it has some drawbacks, such as thermal and mass transfer performance.

Zeolite as an adsorbent in adsorptive system has been proved has good adsorption capacity. However, it has some drawbacks such as it needs high temperature for desorption process compare to silica gel. The problem of these adsorbent particles is thermal resistance due to voids between granules and considerably reduce the effective thermal conductivity of the adsorbent bed. Many efforts have been done to enhance heat transfer performance of the adsorbent bed. Some researchers used metal additives at different mass concentration through the adsorbent bed to study the effect of thermal conductivity. Askalany et al [5] studied the addition of metal particels through granular activated carbon. They found the increasing of thermal conductivity increased as well as the increase of metal concentration. Rezk et al. [6] and
Demir et al. [7] investigated the improvement of thermal performance by adding metal particles through granular silica gel bed. In their study, Rezk et al. [6] found the deviation of less than 15\% compared to an experiment conducted by Demir et al. [7].

This paper discusses the effect of metal particles addition into zeolite bed to enhance heat transfer performance. The effective thermal conductivity is calculated by adding aluminium, copper, brass, and steel to the adsorbent bed. Moreover, the adsorption capacity is also calculated to predict the effect of volumetric fraction of metal additives.

\section{METHODOLOGY}

In this work, zeolite is packed on the inside diameter of the cylinder. Different weight percentages of 5\%, 10\%, and $15 \%$ of metal pieces (aluminum, steel, copper, and brass) are added to make a zeolite-metal mixture. Furthermore, this packed bed is assumed to be one solid mixture to calculate the overall heat transfer coefficient. Annulus inside diameter (ri), annulus outside diameter (ro), lenght (l), and thickness of the bed as shown in figure 1 is $12.5,66,70.4$, and $3 \mathrm{~mm}$, respectively.

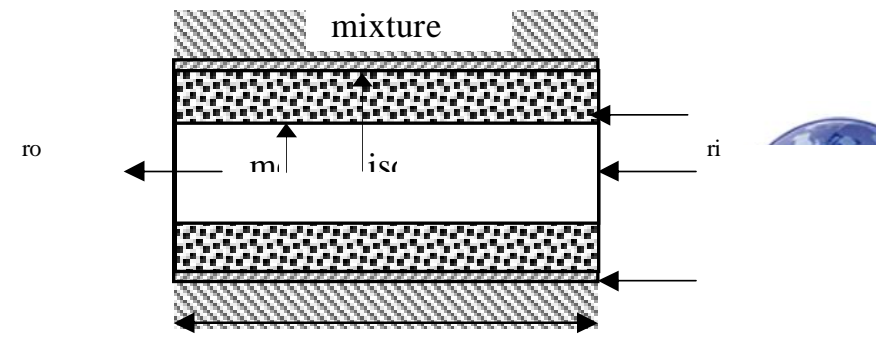

Figure 1: Adsorption bed

Volume based two phase effective thermal conductivity formula proposed by Hamilton and Crosser [8] was used to predict thermal conductivity of two components mixture. The formula was determined as:

$K=\left[k_{\text {metal }} V_{\text {metal }}(d T / d x)_{\text {metal }}+k_{\text {ads }} V_{\text {ads }}(d T / d x)_{\text {ads }}\right] /\left[V_{\text {metal }}(d T / d x)_{\text {metal }}+V_{\text {ads }}(d T / d x)_{\text {ads }}\right]$

where $\mathrm{k}$ and $\mathrm{V}$ are the thermal conductivity and volume fraction respectively, while $(\mathrm{dT} / \mathrm{dx})$ is overall average 
Andi Taufan et al., International Journal of Emerging Trends in Engineering Research, 8(8), August 2020, $4773-4776$

temperature gradient which determined in equation 2 below: $\left.(d T / d x)_{\text {metal }} /(d T / d x)_{\text {ads }}=n k_{\text {metal }} / k_{\text {ads }}+(n-1) k_{\text {metal }}\right]$

Material parameter used in calculation is shown in Table 1. [8-11].

Table 1: Parameter values

\begin{tabular}{lccc}
\hline Material & $\mathbf{n}$ & $\begin{array}{c}\mathbf{K} \\
(\mathbf{W} / \mathbf{m} \mathbf{K})\end{array}$ & $\begin{array}{c}\text { Density } \\
(\mathbf{k g} / \mathbf{m 3})\end{array}$ \\
\hline Alumunium & 1.031 & 237 & 2702 \\
Copper & 1.047 & 401 & 8933 \\
Brass & 1.11 & 150 & 8500 \\
Steel & 2.331 & 14.9 & 7900 \\
Zeolite & - & 0.097 & 590 \\
\hline
\end{tabular}

Energy balances of the system consists of energy balance in the air, the adsorbent, and the metal cylinder. This calculation is used to investigate direct effect of thermal conductivity enhancement to thermal performance.

The energy balance in the air is written as

$$
\begin{aligned}
& \dot{q_{\text {in }}}=q_{\text {out }} \\
& \dot{m_{\text {air }}} C p_{\text {air }} T_{\text {air }, \text { in }}=q_{\text {conv }}+\dot{m}_{\text {air }} C p_{\text {air }} T_{\text {air }, \text { out }} \\
& \dot{m}_{\text {air }} C p_{\text {air }}\left(T_{\text {air, in }}-T_{\text {air }, \text { out }}\right)=q_{\text {conv }}
\end{aligned}
$$

where

$$
\begin{aligned}
& q_{\text {conv }}=h A\left(\overline{T_{\text {air }}}-\overline{T_{\text {ads }}}\right) \\
& \overline{T_{\text {air }}}=\left(T_{\text {air }, \text { in }}-T_{\text {air }, \text { out }}\right) / 2 \\
& \overline{T_{\text {ads }}}=\left(T_{\text {ads }, i}-T_{\text {ads }, i+1}\right) / 2
\end{aligned}
$$

The energy balance in the adsorbent/mixture is written as

$$
\begin{gathered}
q_{\text {conv }}=\Delta U_{\text {ads }}+q_{\text {cond }} \\
m_{a d s} C p_{a d s} \frac{\left(T_{a d s, i+1}-T_{a d s, i}\right)}{d t}=q_{c o n v}-\frac{2 \pi k_{e f f} l}{\ln \left(r_{o} / r_{i}\right)}\left(\overline{T_{z}}-T_{s 2}\right)
\end{gathered}
$$

The energy balance in the metal cylinder is written as

$$
q_{\text {cond }}=\Delta U_{m}
$$

\section{RESULT AND DISCUSSION}

Calculation in this work was compared to an experiment conducted by Demir et al. [7] who used silica gel with thermal conductivity of $0.106 \mathrm{~W} / \mathrm{m} \mathrm{K}$. As shown in Table 2, a comparison between this work and the other work resulted in a deviation of $2.3 \%$. Same method than used to calculate the effective thermal conductivity of the zeolite-metal mixtures with $0.097 \mathrm{~W} / \mathrm{m} \mathrm{K}$ zeolite thermal conductivity.

Figure 1 shows predicted results of effective thermal conductivity for each percentage of metal additives. Thermal conductivity improvement with additional metal additives into the bed can be seen in figure 1 . This figure shows that aluminum has the highest effect among metal additives in each percentage. The enhancement of the thermal conductivity reaches the maximum as $0.375 \mathrm{~W} / \mathrm{m} \mathrm{K}$ when $15 \%$ wt of aluminum is added into the bed. It improves $286 \%$ compare to the zeolite thermal conductivity. Copper, brass, and steel with $15 \%$ wt improve the effective thermal conductivity of $217 \%, 188 \%$, and $115 \%$, respectively. Minimum enhancement resulted from adding 5\%wt steel followed by brass, copper, and aluminum with the effective thermal conductivity and improvement of $0.130,0.152$, 0.160 , and $0.180 \mathrm{~W} / \mathrm{m} \mathrm{K}$, respectively; and 34\%, 56\%, 65\%, and $85 \%$, respectively. The more metal addition, the higher the impact on effective thermal conductivity improvement.

Table 2 : Comparison between this calculated method and the experiment

\begin{tabular}{|l|c|c|c|c|}
\hline $\begin{array}{c}\text { Adsorb } \\
\text { ent }\end{array}$ & Metal & $\begin{array}{c}\text { Weight } \\
\text { percentage }\end{array}$ & $\begin{array}{c}\text { Calculated } \\
\text { Keff } \\
\text { (W/mK }\end{array}$ & $\begin{array}{c}\text { Experim } \\
\text { ent by } \\
\text { Demir et } \\
\text { al [7] } \\
\text { Keff } \\
\text { (W/mK) }\end{array}$ \\
\hline $\begin{array}{l}\text { Silica } \\
\text { gel }\end{array}$ & - & - & 0.106 & 0.106 \\
\hline $\begin{array}{l}\text { Silica } \\
\text { gel }\end{array}$ & $\mathrm{Al}$ & $5 \%$ & 0.189 & 0.218 \\
\hline $\begin{array}{l}\text { Silica } \\
\text { gel }\end{array}$ & & $10 \%$ & 0.2581 & 0.314 \\
\hline $\begin{array}{l}\text { Silica } \\
\text { gel }\end{array}$ & $15 \%$ & 0.384 & 0.363 \\
\hline $\begin{array}{l}\text { Silica } \\
\text { gel }\end{array}$ & $\mathrm{Cu}$ & $5 \%$ & 0.169 & 0.187 \\
\hline $\begin{array}{l}\text { Silica } \\
\text { gel }\end{array}$ & & $10 \%$ & 0.239 & 0.246 \\
\hline $\begin{array}{l}\text { Silica } \\
\text { gel }\end{array}$ & & $15 \%$ & 0.317 & 0.324 \\
\hline $\begin{array}{l}\text { Silica } \\
\text { gel }\end{array}$ & Brass & $5 \%$ & 0.161 & 0.176 \\
\hline $\begin{array}{l}\text { Silica } \\
\text { gel }\end{array}$ & & $10 \%$ & 0.221 & 0.211 \\
\hline $\begin{array}{l}\text { Silica } \\
\text { gel }\end{array}$ & Steel & $5 \%$ & 0.139 & 0.141 \\
\hline $\begin{array}{l}\text { Silica } \\
\text { gel }\end{array}$ & $10 \%$ & 0.176 & 0.169 \\
\hline $\begin{array}{l}\text { Silica } \\
\text { gel }\end{array}$ & & $15 \%$ & 0.217 & 0.254 \\
\hline $\begin{array}{l}\text { Silica } \\
\text { gel }\end{array}$ & & 527 & 0.327 \\
\hline
\end{tabular}

The figure also shows that the enhancement of aluminum and copper with a lower weight percentage of the metal additive have higher enhancement than the steel with a higher weight percentage. It is caused by a significant difference in metal thermal conductivity between these metals. Aluminum with a 
lower thermal conductivity than copper has more significant improvement due to the model used in the calculation uses volume-based so that it affects the final results from volume fraction of the metal.

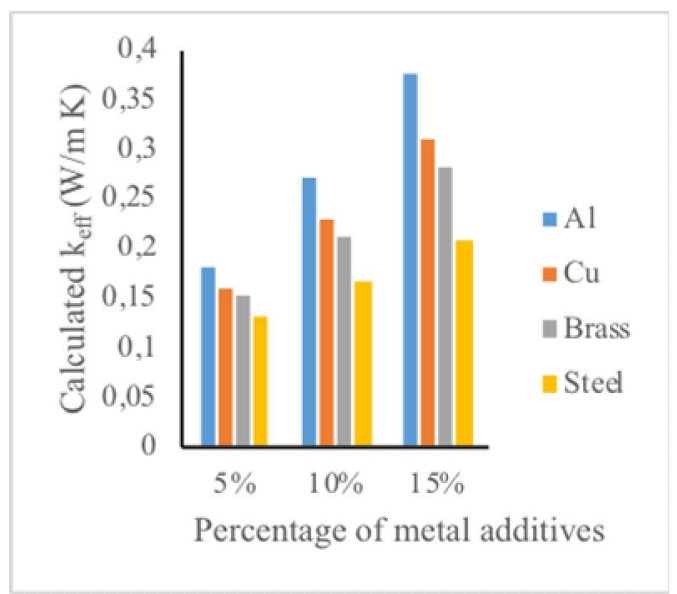

(a)

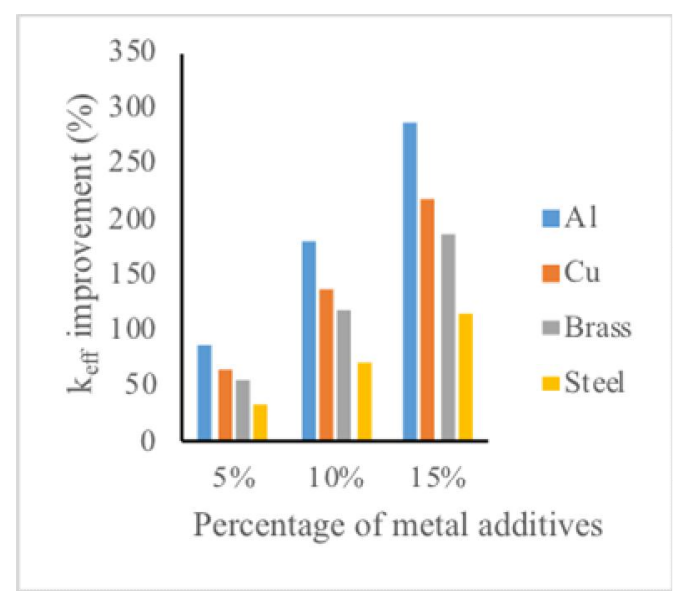

(b)

Figure 2: (a) Prediction thermal conductivity, (b) Thermal conductivity enhancement each percentage of metal aditives

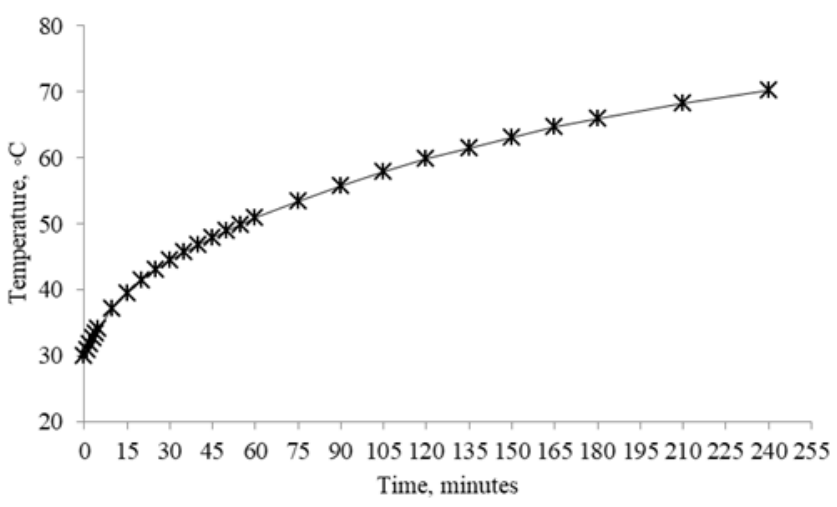

Figure 3: Temperature of Desiccant with metal additive $15 \% \mathrm{Al}$

Figure 2 shows the temperature increase of zeolite-Al 15\% wt during the heating process with input ait temperature and mass flow rate of $80^{\circ} \mathrm{C}$ and $0.02 \mathrm{~kg} / \mathrm{s}$, respectively. The increase in temperature slows down throughout the heating time, due to the smaller temperature difference between the air and the zeolite mixture. The figure also shows that the heat transfer from hot air to zeolite mixture is too low because of the bed dimension is too small. From the graph, it needs a long time the zeolite mixture temperature to reach given hot air temperature. Even after 4 hours, the temperature difference is around $10^{\circ} \mathrm{C}$. This can be overcome by increasing the contact area between the air and the zeolite mixture. For the same volume and mass, the bed can be made with a longer size and a thinner zeolite thickness.

If the system is considered on steady pressure and temperature where is the system is also considered been heated from the outside diameter, then absorb water vapor in inside diameter. The amount of vapor taken, which depends on pressure and temperature, can be defined by various equations. Freundlich, Dubinin-Astakhov, Langmuir, Henry's, and Toth 's equations are the most general equation. The three-term Langmuir equation commonly uses to calculate zeolite-water isotherm. This isotherm, which is used in this study, describes in Ben Amar et al. [11], where pressure and temperature are assumed about $3.255 \mathrm{kPa}$ (zeolite-water pressure range is $0.87-7.38$ $\mathrm{kPa}[12])$ and $25 \mathrm{oC}$.

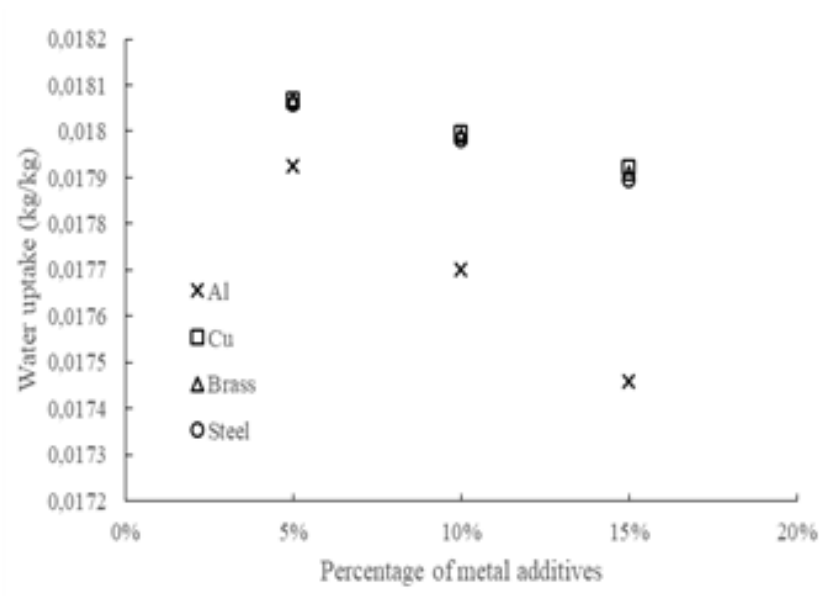

Figure 4 : Amount of water vapor

Figure 4 shows aluminum which has the lightest density affects the water uptake the lowest. Contrary, a copper, which has the heaviest density among the metal additives, has the highest water uptake. No significant difference in water uptake between copper, brass, and steel at each metal additive percentage due to their density is pretty close.

Water uptake of the bed decreases linearly with the increase of metal additive percentage. The metal additive that has lighter density takes more space in the bed. Therefore, a volumetric fraction of adsorbent will be low; hence, the mass of adsorbent is low as well. The amount of the adsorbent mass indicates the amount of water can be adsorbed. 
Furthermore, it needs optimized before decide the best bed design due to the opposite results of the effective thermal conductivity with the water uptake. The objectives should be the price with constraints of heat and mass transfer performances. Other relevant references on heat transfer [13], [14] can be further explored.

\section{CONCLUSION}

This study shows enhancement of heat transfer performance by addition of metal particles through the adsorption bed. The comparison between each metal additive revealed that the more metal addition, the higher the impact on effective thermal conductivity improvement. Aluminium enhances thermal performance better than other metal additives. The thermal conductivity of $15 \%$ wt of aluminium improves $286 \%$ compare to the zeolite thermal conductivity, followed by copper, brass, and steel of $217 \%, 188 \%$, and $115 \%$, respectively. Minimum enhancement resulted from adding $5 \%$ wt steel followed by brass, copper, and aluminum with the effective thermal conductivity and improvement of 0.130 , $0.152,0.160$, and $0.180 \mathrm{~W} / \mathrm{m} \mathrm{K}$, respectively; and $34 \%, 56 \%$, $65 \%$, and $85 \%$, respectively.

\section{REFERENCES}

1. D. C. Wang, Z. Z. Xia, J. Y. Wu, R. Z. Wang, H. Zhai, and W. D. Dou. Study of a novel silica gel-water adsorption chiller. Part I. Design and performance prediction, Int. J. Refrig, vol. 28, no.7, pp. 1073-1083, 2005.

2. T. S. Ge, D. Qi, Y. J. Dai, and R. Z. Wang, R. Experimental testing on contaminant and moisture removal performance of silica gel desiccant wheel, Energy and Building, vol. 176, pp. 71-77, 2018.

3. S. Hanif, M. Sultan, T. Miyazaki, and S. Koyama. Steady-state Investigation of Desiccant Drying System for Agricultural Applications Steady-state Investigation of Desiccant Drying System for Agricultural Applications, Evergr. Jt. J. Nov. Carbon Resour. Sci. Green Asia Strateg, vol. 5, no. 1, pp. 33-42 2018. https://doi.org/10.5109/1929728

4. M. Yahya. Experimental and theoretical performances of a solar assisted dehumidification drying system for heat sensitive products, Jurnal Momentum, vol. 14, no.1, pp. 63-76, 2013.
5. A. A. Askalany, S. K. Henninger, M. Ghazy, and B. B. Saha. Effect of improving thermal conductivity of the adsorbent on performance of adsorption cooling system, Applied Thermal Engineering, vol.110, pp. 695-702, 2017.

6. A. Rezk, S. Mahmoud, and A. Elsayed. Effects of contact resistance and metal additives in fi nned-tube adsorbent beds on the performance of silica gel / water adsorption chiller, Applied Thermal Engineering, vol. 53, no.2, pp. 278-284, 2013.

7. H. Demir, M. Mobedi, and U. Semra. The use of metal piece additives to enhance heat transfer rate through an unconsolidated adsorbent bed 'talliques utilise' $s$ afin Additifs sous forme de particules me ` travers un lit absorbant d' augmenter le transfert de chaleur a non consolide, Int. J. of refrigeration, vol. 33, no.4, pp. 714-720, 2010.

8. R. L. Hamilton, and O. K. Crosser. Thermal conductivity of hetrogeneous two component systems. Ind. Eng. Chem. Fundam, vol. 1, no. 3, pp. 187-19, 1962.

9. F. P. Incropera, D P. Dewitt, T. L. Bergman, and A. S. Lavine. Fundamentals of heat and mass transfer, John Willey \& Son, 2007.

10. A. R. M. Rezk. Theoretical and Experimental Investigation of Silica Gel / Water Adsorption Refrigeration Systems, Doctoral dissertation University of Birmingham, London, 2012.

11. N. B. Amar, L. M. Sun, and F. Meunier. Numerical analysis of adsorptive wave regenerative heat temperature pump, Appl. Therm. Eng, vol. 16, no. 5, pp. 405-418, 1996.

12. Z. E. Yildirim. A Study on Isotherm Characteristics of Adsorbent-Adsorbate Pairs Used in Adsorption Heat Pumps, Master Thesis, İzmir Institute of Technology, 2011.

13. Smirnova Zhanna, V., Vaganova, O.I., Kutepova, L.I., Kuttepov, M.M., Chaykina, Z.V. Steel heat treatment technology, International Journal of Emerging Trends in Engineering Research 8(5),49, pp. 1790-1793, 2020. https://doi.org/10.30534/ijeter/2020/49852020

14. Usikov, S.M. Simulation of heat transfer by water heating convectors, International Journal of Emerging Trends in Engineering Research 8(3),19, pp. 726-734, 2020.

https://doi.org/10.30534/ijeter/2020/19832020 